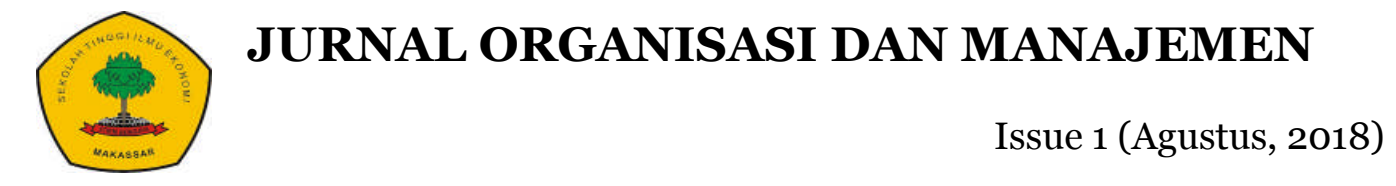

https://doi.org/10.31219/osf.io/79ext

\title{
Pengaruh Kinerja Keuangan Terhadap Harga Saham
}

\author{
Andi Aspar Ramadhana1), Herman Sjahruddin 2), Suseno Hadi Purnomo ${ }^{3)}$ \\ andiaspar22@gmail.com \\ 1) Mahasiswa Program Studi Manajemen pada Sekolah Tinggi Ilmu Ekonomi \\ Bongaya Makassar \\ 2,3) Dosen Program Studi Manajemen pada Sekolah Tinggi Ilmu Ekonomi \\ Bongaya Makassar
}

\begin{abstract}
ABSTRAK
Penelitian ini bertujuan untuk menguji dan menganalisis pengaruh Kinerja Keuangan Terhadap Harga Saham . Populasi dalam penelitian ini adalah Laporan keuangan triwulan untuk tahun 2014-2017, Perusahaan industri manufaktur Sektor industri barang konsumsi Sub Sektor rokok yang terdaftar di Bursa Efek Indonesia (BEI) yang berjumlah 4 (empat) perusahaan, namun terdapat 1 (satu) diantaranya yang penyajian laporan keuangannya tidak disajikan secara lengkap, terkait dengan variable yang dianalisis (Return on Asset (ROA), Net Profit Margin (NPM), Debt to Total Assets Ratio (DAR) dan Price Earning ratio (PER) serta closing price saham), sehingga sampel dalam penelitian ini hanya menggunakan 3 emiten saja (PT HM Sampoerna Tbk (HMSP), PT. Gudang Garam Tbk (GGRM), dan PT. Wismilak Inti Makmur Tbk (WIIM)). sehingga keseluruhan data yang digunakan berjumlah 3 X 16 $=48$ unit data. Hasil analisis regresi ganda menunjukkan bahwa ROA berpengaruh negatif dan tidak signifikan terhadap harga saham, variabel NPM berpengaruh positif dan tidak signifikan terhadap harga saham, sedangkan variabel DAR dan PER berpengaruh positif dan signifikan terhadap harga saham.

Kata kunci : $\quad$ ROA, NPM, DAR, PER, Closing Price
\end{abstract}

\begin{abstract}
Regression analysis is constructed for capturing the effect of Financial Performance on Stock Prices. . The sample in this study were all cigarette companies listed on the BEI in the 4 year 2014 to 2017 as many as 3 companies. To achieve the objectives in this study using multiple regression analysis method with SPSS 24 software. The results of this study indicate that partially ROA has a negative and insignificant effect on stock prices, NPM variables have a positive and insignificant effect on stock prices, while the DAR and PER variables have a positive and significant effect on stock prices.
\end{abstract}

Keywords: $\quad$ ROA, NPM, DAR, PER, Closing Price

Halaman 47

Authors : Andi Aspar Ramadhana dkk. (Agustus 2018). 47 - 65 


\section{JURNAL ORGANISASI DAN MANAJEMEN}

Issue 1 (Agustus, 2018)

https://doi.org/10.31219/osf.io/79ext

\section{Latar Belakang}

Pasar modal merupakan salah satu penggerak perekonomian dunia, termasuk Indonesia. Melalui pasar modal perusahaan dapat memperoleh dana untuk melakukan kegiatan perekonomian (Zuliarni, 2012). Pasar modal dalam arti luas adalah sarana bagi pihak dalam hal ini adalah pihak swasta atau pemerintah yang membutuhkan modal jangka panjang dari masyarakat yang biasa disebut sebagai investor. Terdapat banyak faktor yang membuat tertarik berinvetasi dipasar modssl salah satu diantara faktor tersebut adalah factor keuangan, bahwa demakin tinggi, maka semakin tinggi harga perusahaansaham(Zuliarni, 2013, Hutami, 2012, Pamungkas dan Budiyanto, 2013, Anindita, 2017).

Teori yang digunakan dalam menjelaskan pengaruh kinerja keuangan terhadap harga saham, mengacu pada teori Sinyal (Signaling Theory)yang merupakan tindakan yang diambil oleh manajemen perusahaan untuk memberikan petunjuk kepada para investor mengenai bagaimana cara pandang manajemen terhadap prospek perusahaan. Teori ini memiliki makna informasi maupun sinyal untuk memprediksi keadaan perusahaan dimasa yang akan datang. Pemberian signal mengenai kinerja keuangan diharapkan dapat menarik para investor untuk berinvestasi pada perusahaan dengan menggunakan laporan keuangan sebagai bahan pertimbangan. Analisis laporan keuangan terdiri dari beberapa rasio keuangan. Apabila hasil analisis laporan keuangan menunjukkan kinerja perusahaan yang baik, maka investor akan tertarik untuk membeli saham perusahaan di pasar modal. Apabila nilai saham tinggi, maka harga saham akan meningkat di pasar modal. Dan sebaliknya jika nilai saham rendah, maka harga saham akan ikut menurun di pasar modal (Brigham dan Houston, 2011).

Studi yang dilakukan Fatmawati dan Widyawati (2017) menganalisis kinerja keuangan dengan menggunakan return on asset (ROA), net profit margin (NPM), debt to asset ratio (DAR) dan price earning ratio (PER).Hasil studinya membuktikan bahwa ROA berpengaruh positif dan signifikan terhadap harga saham, NPM berpengaruh negatif dan tidak signifikan terhadap harga saham, kemudian DAR dan PER berpengaruh positif dan tidak signifikan terhadap harga saham. Temuan peneliti lainnya memberikan bukti yang berbeda, bahwa ROA berpengaruh positif signifikan terhadap harga saham (Pamungkas dan Budiyanto, 2013), sedangkan hasil penelitian Aryani dan Zulkifli (2017) dan Sardiyati (2016) menyatakan bahwa ROA berpengaruh positif tidak signifikan terhadap harga saham.

Pada pengukuran kinerja keuangan lainnya, ditemukan bukti bahwa NPM berpengaruh positif signifikan terhadap harga saham (Hutami, 2012). Sedangkan hasil penelitian Aryani dan Zulkifli (2017) memperoleh hasil 


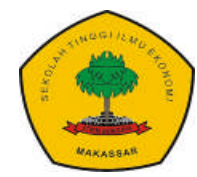

Issue 1 (Agustus, 2018)

https://doi.org/10.31219/osf.io/79ext

yang berbeda yaitu Net Profit Margin berpengaruh negatif signifikan terhadap harga saham. Selanjutnya untuk pengukuran Debt to Asset Ratio (DAR), ditemukan hasil bahwa Debt to Asset Ratio berpengaruh negatif tidak signifikan terhadap harga saham (Anindita, 2017), sedangkan penelitian Rani dan Diantini (2015) menyimpulkan bahwa DAR berpengaruh positif tidak signifikan terhadap harga saham.

Terakhir, untuk Price Earning Ratio (PER) ditemukan hasil penelitian terdahulu yang membuktikan bahwa PER berpengaruh positif signifikan terhadap harga saham (Zuliarni, 2013). Temuan tersebut memperoleh bantahan dari peneliti lainnya (Fitri dan Yahya, 2016) bahwa Price Earning Ratio berpengaruh negatif tidak signifikan terhadap harga saham.

Harga saham diantara beberapa sub sektor yang terdaftar di Bursa Efek Indonesia yang tingkat fluktuasinya senantiasa berubah adalah subsektor industri rokok, hal ini disebabkan karena industri rokok merupakan salah satu penggerak sektor ekonomi di Indonesia. Keberadaan industri rokok banyak mengundang pro-kontra di kalangan masyarakat. Di Indonesia peranan rokok sebagai sumber pemasukan negara saat ini masih besar. Pemasukan dari sektor bea dan cukai, pajak daerah dan PBB dari tembakau dan rokok tahun 2015 tercatat melebihi angka 170 triliun. Di Indonesia ada empat perusahaan rokok di Indonesia yang go publik diantaranya adalah PT HM Sampoerna Tbk (HMSP), PT Bentoel International Investama Tbk (RMBA), PT. Gudang Garam Tbk (GGRM), dan PT. Wismilak Inti Makmur Tbk (WIIM) Penjabaran harga saham dari sub sektor rokok yang terdaftar pada Bursa Efek Indonesia dapat ditunjukkan pada Tabel berikut:

Tabel 1.

Harga Saham Sub Sektor Rokok di Bursa Efek Indonesia 2014 - 2017

\begin{tabular}{|c|c|c|c|c|}
\hline \multirow{2}{*}{ Tahun } & \multicolumn{4}{|c|}{ Harga Saham Penutupan (Rp.) } \\
\cline { 2 - 5 } & RMBA & WIIM & HMSP & GGRM \\
\hline 2014 & 520 & 625 & 2.726 & 6.070 \\
\hline 2015 & 510 & 430 & 3.760 & 5.500 \\
\hline 2016 & 484 & 440 & 3.830 & 6.390 \\
\hline 2017 & 380 & 290 & 4.730 & 8.380 \\
\hline
\end{tabular}

Sumber : Laporan Keuangan BEI, data diolah (2018)

Tabel tersebut menunjukkan bahwa dari ke empat sub sektor rokok yang terdaftar di Bursa Efek Indonesia hanya ada dua perusahaan yang harga sahamnya menunjukkan adanya kenaikan atau peningkatan, yaitu PT. HM Sampoerna Tbk (HMSP) dan PT. Gudang Garam Tbk (GGRM), sedangkan 


\section{JURNAL ORGANISASI DAN MANAJEMEN}

Issue 1 (Agustus, 2018)

https://doi.org/10.31219/osf.io/79ext

untuk PT. Bentoel International Investama Tbk (RMBA) dan PT. Wismilak Inti Makmur Tbk (WIIM) harga saham perusahaan mengalami penurunan.

Harga saham pada tabel 1 menunjukkan adanya fruktuasi (perubahaan harga) serta berdasarkan temuan peneliti terdahulu yang menunjukkan adanya perbedaan temuan dalam menganalisi pengaruh kinerja keuangan terhadap harga saham, hal ini memotivasi peneliti atau menjadi alasan peneliti untuk menganalisis kembali pengaruh kinerja keuangan terhadap harga saham.

\section{Tinjauan Teoritis}

\section{Pengertian manajemen keuangan}

Sutrisno (2000) mengemukakan bahwa manajemen keuangan atau sering disebut pembelanjaan dapat diartikan sebagai semua aktivitas perusahaan yang berhubungan dengan usaha-usaha mendapatkan dana perusahaan dengan biaya yang murah serta usaha menggunakan dan mengalokasikan dana tersebut secara efisien. Martono dan Agus (2005) Manajemen Keuangan (Financial Manajement) adalah segala aktivitas perusahaan yang berhubungan dengan memperoleh dana, menggunakan dana dan mengelola aset sesuai tujuan perusahaan secara menyeluruh. Dengan kata lain berarti manajemen keuangan merupakan manajemen (pengelolaan).

\section{Pengertian dan pengukuran kinerja keuangan}

Kinerja keuangan adalah suatu analisis yang dilakukan untuk melihat sejauh mana suatu perusahaan telah melaksanakan dengan menggunakan aturan-aturan pelaksanaan keuangan secara baik dan benar (Fahmi, 2012). Tinggi rendahnya kinerja keuangan suatu perusahaan dapat diukur dengan menggunakan rasio-rasio keuangan (Fatmawati dan Widyawati, 2017) yaitu:

1) Return of Asset (ROA), rasio ini digunakan untuk mengukur kemampuan manajemen dalam memperoleh keuntungan (laba) secara keseluruhan. Semakin besar ROA, semakin besar pula tingkat keuntungan yang dicapai oleh perusahaan tersebut dan semakin baik pula posisi perusahaan tersebut dari segi penggunaan asset (Dendawijaya, 2003 dalam Rinati, 2012).Tinggi rendahnya rasio ini dapat dihitung dengan menggunakan rumus sebagai berikut (Mabruroh, 2004 dalam Nusantara, 2009):

$$
=\frac{\mathrm{EBT}}{\text { Total aktiva }} \times 100 \%
$$

Authors : Andi Aspar Ramadhana dkk. (Agustus 2018). 47 - 65 


\section{JURNAL ORGANISASI DAN MANAJEMEN}

Issue 1 (Agustus, 2018)

\section{https://doi.org/10.31219/osf.io/79ext}

2) Net Profit Margin (NPM), net profit margin adalah perbandingan antara laba bersih dengan penjualan(Bastian dan Suhardjono 2006 dalam Rinati, 2012). Rasio ini menunjukkan berapa besar persentase laba bersih yang diperoleh dari setiap penjualan. Semakin besar rasio ini, maka dianggap semakin baik kemampuan perusahaan untuk mendapatkan laba yang tinggi. Tinggi rendahnya rasio ini dapat dihitung dengan menggunakan rumus sebagai berikut (Rinati, 2012):

$$
=\frac{\text { Laba Bersih Setelah Pajak }}{\text { Penjualan }} \times 100 \%
$$

3) Debt to Total Asset Ratio (DAR), debt Ratio merupakan rasio utang yang digunakan untuk mengukur perbandingan antara total utang dengan total aktiva. Dengan kata lain, seberapa besar aktiva perusahaan dibiayai oleh utang atau seberapa besar utang perusahaan berpengaruh terhadap pengelolaan aktiva (Kasmir, 2014). Rasio ini dihitung dengan rumus:

$$
=\frac{\text { Total Utang }}{\text { Asset }} \times 100 \%
$$

4) Price Earning Ratio (PER), price earning ratio digunakan untuk menilai murah atau mahal sebuah saham, semakin rendah nilai PER sebuah saham maka semakin baik atau murah harganya untuk diinvestasikan.Tinggi rendahnya rasio ini dapat dihitung dengan menggunakan rumus sebagai berikut (Tandelilin 2010).

$$
\text { PER }=\frac{\text { Harga Saham }}{\text { Earnig Per Lembar Saham }} \times 100 \%
$$

\section{Pengertian dan pengukuran harga saham}

Saham adalah surat berharga yang menunjukkan kepemilikan perusahaan sehingga pemegang saham memiliki hak klaim atas dividen atau distribusi lain yang dilakukan perusahaan kepada pemegang saham lainnya (Sunariyah, 2004). Harga saham adalah nilai nominal penutupan (clossing price) dari penyertaan atau pemilikan seseorang atau badan dalam suatu perusahaan atau perseroan terbatas yang berlaku secara reguler di pasar modal di Indonesia. Menurut Fred dan Copeland (1999) dalam Rinati (2012), Penelitian yang dilakukan Fatmawati dan Widyawati (2017) mengukur harga saham suatu perusahaan dengan menggunakan nilai nominal penutupan (clossing price) dari penyertaan atau pemilikan seseorang atau badan dalam suatu perusahaan atau perseroan terbatas yang berlaku secara reguler di pasar modal di Indonesia. 


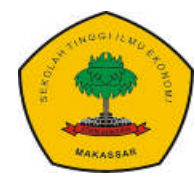

JURNAL ORGANISASI DAN MANAJEMEN

Issue 1 (Agustus, 2018)

https://doi.org/10.31219/osf.io/79ext

Metode Penelitian

Berdasarkan jenisnya, penelitiian ini tergolong dalam pendekatan kuantiitatif yang menggunakan angka-angka sebagai data penelitian, pendekatan dalam penelitian ini adalah pedekatan cross sectional (pengamatan sesaat) atau penelitian dengan melakukan pengukuran atau pengamatan pada saat bersamaan atau sekali waktu .

\section{Hasil Penelitian}

\section{Hasil Uji Asumsi Klasik}

Sebelum dilakukan pengujian hipotesis menggunakan analisis regresi sederhana. Ada beberapa uji asumsi klasik yang harus dipenuhi agar kesimpulan dan regresi tersebut tidak bias.

\section{a. Uji Autokorelasi}

Tabel 2

Uji Autokerelasi

\begin{tabular}{rrr|r|r|r} 
Model & $\mathrm{R}$ & $\begin{array}{c}\mathrm{R} \\
\text { Square }\end{array}$ & $\begin{array}{c}\text { Adjusted } \\
\mathrm{R} \\
\text { Square }\end{array}$ & $\begin{array}{l}\text { Durbin- } \\
\text { Watson }\end{array}$ \\
\hline & 1 & $.622^{\mathrm{a}}$ & 0.387 & 0.33 & 1.050 \\
\hline
\end{tabular}

a. Predictors: (Constant), PER, NPM, DAR, ROA

b. Dependent Variable: H_SAHAM

Sumber: SPSS 24, data diolah (2018)

Berdasarkan hasil uji autokorelasi pada model summary menunjukkan bahwa nilai dl (batas atas) $=4$ dan du (batas bawah) $=0$ hasil pengujian membuktikan bahwa nilai autokerelasi sebesar 1.196 dengan demikian dapat dinyatakan bahwa $0<1.050<4-0$ sehingga keputusan hasil uji autokorelasi tersebut adalah tidak ada autokorelasi positif atau negatif.

\section{b. Uji Multikolonieritas}

Tabel 3

Hasil Uji Multikolonieritas

\begin{tabular}{|c|c|c|c|c|c|c|}
\hline \multirow{2}{*}{ Model } & \multicolumn{2}{|c|}{ Standardized Coefficients } & \multirow{2}{*}{$\mathrm{T}$} & \multirow{2}{*}{ Sig. } & \multicolumn{2}{|c|}{$\begin{array}{l}\text { Collinearity } \\
\text { Statistics }\end{array}$} \\
\hline & \multicolumn{2}{|c|}{ Beta } & & & Tolerance & VIF \\
\hline \multirow[t]{5}{*}{1} & (Constant) & & 3.392 & 0.001 & & \\
\hline & ROA & -0.108 & -0.644 & 0.523 & 0.504 & 1.984 \\
\hline & NPM & 0.286 & 1.661 & 0.104 & 0.479 & 2.088 \\
\hline & DAR & 0.319 & 2.503 & 0.016 & 0.876 & 1.142 \\
\hline & PER & 0.368 & 2.949 & 0.005 & 0.914 & 1.095 \\
\hline
\end{tabular}

a. Dependent Variable: H_SAHAM

Sumber: SPSS 24, data diolah (2018)

Berdasarkan Tabel 3 dapat diketahui bahwa nilai tolerance dari semua variabel independen dalam penelitian ini mempunyai nilai tolerance $>0,10$

Authors : Andi Aspar Ramadhana dkk. (Agustus 2018). 47 - 65 
https://doi.org/10.31219/osf.io/79ext dan $\mathrm{VIF}<10$, yang berarti data yang digunakan dalam penelitian tidak terjadi multikolonearitas data (Bahar dan Sjahruddin , 2017).

\section{c. Uji Normalitas}

Tabel 4

Hasil Uji Normalitas

\begin{tabular}{|l|l|r|}
\hline \multicolumn{2}{|c|}{} & \multicolumn{2}{|c|}{$\begin{array}{c}\text { Unstandardized } \\
\text { Residual }\end{array}$} \\
\hline $\mathrm{N}$ & Mean & .0000000 \\
\cline { 2 - 3 } Normal Parameters ${ }^{\mathrm{a}, \mathrm{b}}$ & Std. Deviation & 1.61078905 \\
\hline \multirow{2}{*}{ Most Extreme Differences } & Absolute & .118 \\
\cline { 2 - 3 } & Positive & .118 \\
\cline { 2 - 3 } & Negative & -.097 \\
\hline Test Statistic & & .118 \\
\hline Asymp. Sig. (2-tailed) & & $.091^{\mathrm{c}}$ \\
\hline
\end{tabular}

a. Test distribution is Normal.

b. Calculated from data.

c. Lilliefors Significance Correction.

Sumber: SPSS 24, data diolah (2018)

Dari hasil uji normalitas diatas diketahui bahwa nilai signifikansi dari uji Kolmogorov-Smimov sebesar $0.091>0.05$, sehingga berdasarkan hasil tersebut maka nilai tersebut lebih besar dari 0.05 ( $p>0.05$ ), sehingga dapat disimpulkan bahwa data yang di uji terdistribusi normal.

\section{d. Uji Heterokedastisitas}

Tabel 5

Uji Heterokedastisitas

\begin{tabular}{|l|l|c|c|c|}
\hline \multicolumn{2}{|c|}{ Model } & Standardized Coefficients & \multirow{2}{*}{ Sig. } & \\
\cline { 3 - 5 } & Beta & 0.994 & 0.326 \\
\hline \multirow{3}{*}{1} & (Constant) & -0.009 & -0.046 & 0.964 \\
\cline { 2 - 5 } & ROA & 0.172 & 0.824 & 0.414 \\
\cline { 2 - 5 } & NPM & 0.163 & 1.057 & 0.297 \\
\cline { 2 - 5 } & DAR & 0.156 & 1.034 & 0.307 \\
\cline { 2 - 5 } & PER & \multicolumn{3}{l}{} \\
\hline \multicolumn{2}{|l|}{ a. Dependent Variable: Hetero }
\end{tabular}

Sumber: SPSS 24, data diolah (2018)

Berdasarkan hasil pengujian uji heterokedasititas pada tabel 5 menunjukkan bahwa variabel independen dalam penelitian ini yaitu ROA memiliki nilai signifikan 0.964>0.05, NPM memiliki niliai signifikan $0.414>$ 0.05, DAR memiliki nilai signifikan $0.297>0.05$ sedangkan PER memiliki niliai signifikan 0,307 $>0.05$. Berdasarkan hasil tersebut (Sjahruddin, H. 


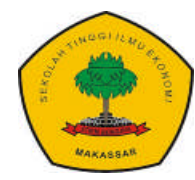

JURNAL ORGANISASI DAN MANAJEMEN

Issue 1 (Agustus, 2018)

https://doi.org/10.31219/osf.io/79ext

2014) maka dapat disimpulkan bahwa data dalam penelitian ini tidak terdapat heterokedastisitas terlihat dari nilai signifikan $>0.05$

\section{Hasil statistik deskriptif}

Tabel 6

statistik deskriptif

\begin{tabular}{|l|r|r|r|}
\hline & Mean & Std. Deviation & N \\
\hline H_SAHAM & 8.3856 & 2.05806 & 48 \\
\hline ROA & 2.2726 & .85859 & 48 \\
\hline NPM & 2.1452 & .45916 & 48 \\
\hline DAR & -1.0819 & .31663 & 48 \\
\hline PER & 2.9859 & 1.09156 & 48 \\
\hline
\end{tabular}

Sumber: SPSS 24, data diolah (2018)

Pada tabel 6 menunjukkan bahwa variabel independen dalam penelitian ini yaitu ROA $\left(\mathrm{X}_{1}\right)$ memiliki nilai mean2.2726, sedangkan nilai deviasinya 0.85859. untuk variabel NPM $\left(\mathrm{X}_{2}\right)$ memiliki nilai mean2.1452, sedangkan nilai deviasinya 0.45916 . DAR $\left(\mathrm{X}_{3}\right)$ memiliki nilai mean sebesar 1.0819sedangkan nilai deviasinya 0.31663 , untuk variabel independe terakhir yaitu PER $\left(\mathrm{X}_{4}\right)$ memiliki nilai mean sebesar 2.9859sedangkan nilai deviasinya1.09156. Sedangkan variabel dependen dalam penelitian ini yaitu harga saham (Y) memiliki nilai mean sebesar 8.3856sedangkan nilai deviasinya2.05806. Sehingga berdasarkan hasil pengujian deskriptif tersebut dapat disimpulkan bahwa semua variabel dalam penelitian ini baik variabel independen dan dependen memiliki nilai mean lebih besar di bandingkan nilai standar deviasinya sehingga data mean merupakan representasi yang baik baik terhadap data penelitian.

\section{Analisis Regresi Berganda}

Tabel 7

Regresi Berganda

\begin{tabular}{|c|c|c|c|c|c|c|}
\hline \multirow{2}{*}{\multicolumn{2}{|c|}{ Model }} & \multicolumn{2}{|c|}{$\begin{array}{l}\text { Unstandardized } \\
\text { Coefficients }\end{array}$} & \multirow{3}{*}{ 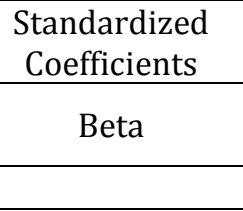 } & \multirow{3}{*}{$\begin{array}{c}\mathrm{t} \\
3.392 \\
\end{array}$} & \multirow{3}{*}{$\begin{array}{l}\text { Sig. } \\
0.001 \\
\end{array}$} \\
\hline & & \multirow{2}{*}{$\begin{array}{l}\text { B } \\
6.393 \\
\end{array}$} & \multirow{2}{*}{$\begin{array}{c}\begin{array}{c}\text { Std. } \\
\text { Error }\end{array} \\
1.885\end{array}$} & & & \\
\hline \multirow{5}{*}{1} & (Constant) & & & & & \\
\hline & ROA & -0.26 & 0.403 & -0.108 & -0.644 & 0.523 \\
\hline & NPM & 1.284 & 0.773 & 0.286 & 1.661 & 0.104 \\
\hline & DAR & 2.075 & 0.829 & 0.319 & 2.503 & 0.016 \\
\hline & PER & 0.694 & 0.235 & 0.368 & 2.949 & 0.005 \\
\hline
\end{tabular}

Sumber: SPSS 24, data diolah (2018)

Halaman 54

Authors : Andi Aspar Ramadhana dkk. (Agustus 2018). 47 - 65 


\section{JURNAL ORGANISASI DAN MANAJEMEN}

Issue 1 (Agustus, 2018)

https://doi.org/10.31219/osf.io/79ext

Dari hasil pengujian pada tabel 7 diatas, maka dapat disimpulkan hasil dari persamaan regresi sederhana sebagai berikut:

$Y=\alpha+\beta_{1} X_{1}+\beta_{2} X_{2}+\beta_{3} X_{3}+\beta_{4} X_{4}+e$

$\mathrm{Y}($ Harga Saham $)=6.393($ konstanta $)-0.108(\mathrm{ROA})+0.286(\mathrm{NPM})+0.319$

$(\mathrm{DAR})+0.368(\mathrm{PER})+0.403$ (standard eror)

Hasil regresi sederhana di atas dapat di Interpretasi sebagai berikut:

1) Konstanta 6.393, menunjukkan bahwa jika variabelReturn On Asset $\left(\mathrm{ROA}, \mathrm{X}_{1}\right)$, Net Profit Margin (NPM, $\mathrm{X}_{2}$ ), Debt to Asset Ratio (DAR, $\mathrm{X}_{3}$ ), Price Earnig Ratio $\left(\mathrm{PER}, \mathrm{X}_{4}\right)$ samadengan nol maka harga saham (Y) akan mengalami peningkatan sebesar6.393.

2) Koefisien regresi - 0.108 berarti jika variabel Return On Asset $\left(\mathrm{ROA}, \mathrm{X}_{1}\right)$ meningkat satu satuan, maka nilai harga saham $(\mathrm{Y})$ akan mengalami penurunan sebesar 0.108 satuan dengan syarat variabel independen lainnya tetap.

3) Koefisien regresi 0.286 berarti jika variabel Net Profit Margin $\left(\mathrm{NPM}, \mathrm{X}_{2}\right)$ meningkat satu satuan, maka nilai harga saham (Y) akan mengalami peningkatansebesar 0.286 satuan dengan syarat variabel independen lainnya tetap.

4) Koefisien regresi 0.319 berarti jika variabel Debt to Asset Ratio $\left(\mathrm{DAR}, \mathrm{X}_{3}\right)$ meningkat satu satuan, maka nilai harga saham (Y) akan mengalami peningkatansebesar 0.319 satuan dengan syarat variabel independen lainnya tetap

5) Koefisien regresi 0.368 berarti jika variabel Price Earnig Ratio $\left(\mathrm{PER}, \mathrm{X}_{4}\right)$ meningkat satu satuan, maka nilai harga saham $(\mathrm{Y})$ akan mengalami peningkatansebesar 0.368 satuan dengan syarat variabel independen lainnya teta

\section{Hasil Pengujian Hipotesis}

\section{a. Uji Kelayakan Model (Fisher test)}

Tabel 8

Uji Kelayakan Model (Fisher test)

\begin{tabular}{|l|l|r|r|r|r|r|}
\hline \multicolumn{2}{|l|}{ Model } & Sum of Squares & df & Mean Square & F & Sig. \\
\hline \multirow{4}{*}{1} & Regression & 77.126 & 4 & 19.282 & 6.799 & $.000^{\mathrm{b}}$ \\
\cline { 2 - 7 } & Residual & 121.948 & 43 & 2.836 & & \\
\cline { 2 - 8 } & Total & 199.074 & 47 & & & \\
\hline
\end{tabular}

a. Dependent Variable: H_SAHAM

b. Predictors: (Constant), PER, NPM, DAR, ROA

Sumber: SPSS 24, data diolah (2018)

Authors : Andi Aspar Ramadhana dkk. (Agustus 2018). 47 - 65 


\section{JURNAL ORGANISASI DAN MANAJEMEN}

Issue 1 (Agustus, 2018)

https://doi.org/10.31219/osf.io/79ext

Nilai F-tabel berpedoman pada nilai df1 dan df2 sehingga berdasarkan tabel diatas, maka nilai df1 dan df2 yaitu 4 dan 43 . Penentuan nilai f-tabel dilakukan dengan menggunakan bantuan MS Excell melalui penggunaan formulasi $\mathrm{FINV}=(0,05,4,43)$ sehingga diperoleh nilai F-tabel dalam penelitian iini yaitu $2.588<6.799 \mathrm{~F}$ hitung, sehingga disimpulkan bahwa data yang dianalisis memenuhi pengujian kelayakan model regresi (Astuti, W. S dkk., 2018).

\section{b. Uji-t (parsial).}

\section{Tabel 9}

Uji-t

\begin{tabular}{|c|c|c|c|c|c|c|}
\hline \multirow{2}{*}{\multicolumn{2}{|c|}{ Model }} & \multicolumn{2}{|c|}{$\begin{array}{c}\text { Unstandardized } \\
\text { Coefficients }\end{array}$} & \multirow{2}{*}{$\begin{array}{c}\begin{array}{c}\text { Standardized } \\
\text { Coefficients }\end{array} \\
\text { Beta }\end{array}$} & \multirow{2}{*}{$\mathrm{t}$} & \multirow{2}{*}{ Sig. } \\
\hline & & B & $\begin{array}{l}\text { Std. } \\
\text { Error }\end{array}$ & & & \\
\hline \multirow{5}{*}{1} & (Constant) & 6.393 & 1.885 & & 3.392 & 0.001 \\
\hline & ROA & -0.26 & 0.403 & -0.108 & -0.644 & 0.523 \\
\hline & NPM & 1.284 & 0.773 & 0.286 & 1.661 & 0.104 \\
\hline & DAR & 2.075 & 0.829 & 0.319 & 2.503 & 0.016 \\
\hline & PER & 0.694 & 0.235 & 0.368 & 2.949 & 0.005 \\
\hline
\end{tabular}

Sumber: SPSS 24, data diolah (2018)

Tabel koefisien regresi digunakan untuk menguji pengaruh antara variabel yang dibangun dalam penelitian ini. Pembuktian hipotesis dapat dilakukan dengan membandingkan nilai t-hitung dengan t-tabel. Nilai t-tabel berpedoman pada nilai $\mathrm{df}=\mathrm{n}-\mathrm{k}-1$, sehingga diperoleh nila df sebesar 43 (48-4-1). Penelusuran nilai t-tabel dilakukan dengan menggunakan bantuan MS Excell melalui penggunaan formulasi TINV= $(0,05,43)$ sehingga diperoleh nilai t-tabel sebesar 2,016.

\section{c. Uji Determinasi $\left(\mathbf{R}^{2}\right)$}

Tabel 10

Uji Determinasi

Model

$\mathrm{R}$

R Square

Sumber: SPSS 24, data diolah (2018)

Berdasarkan tabel 10 di atas, dapat disimpulkan bahwa nilai $\mathrm{R}^{2}$ sebesar 0.387 menunjukkan bahwa pengaruh variabel bebas (Independen)

Halaman 56

Authors : Andi Aspar Ramadhana dkk. (Agustus 2018). 47 - 65 


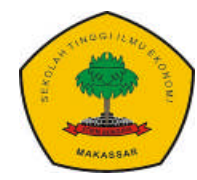

Issue 1 (Agustus, 2018)

https://doi.org/10.31219/osf.io/79ext

yaitu Return On Asset (ROA, $\mathrm{X}_{1}$ ), Net Profit Margin (NPM, $\mathrm{X}_{2}$ ), Debt to Asset Ratio (DAR, $\left.\mathrm{X}_{3}\right)$, Price Earnig Ratio $\left(\mathrm{PER}, \mathrm{X}_{4}\right)$ terhadap harga saham $(\mathrm{Y})$ sebesar $38.7 \%$, sedangkan sisanya sebesar $61.3 \%$ dipengaruhi oleh faktor lain yang tidak dijelaskan dalam penelitian ini.

\section{d. Uji Koefisien Korelasi (R)}

Tabel 11

Koefisien Korelasi

\begin{tabular}{|c|c|c|c|c|c|c|}
\hline & & H_SAHAM & ROA & NPM & DAR & PER \\
\hline \multirow[t]{5}{*}{ Pearson Correlation } & H_SAHAM & 1.000 & .103 & .356 & .426 & .436 \\
\hline & ROA & .103 & 1.000 & .674 & .226 & -.146 \\
\hline & NPM & .356 & .674 & 1.000 & .348 & .086 \\
\hline & DAR & .426 & .226 & .348 & 1.000 & .086 \\
\hline & PER & .436 & -.146 & .086 & .086 & 1.000 \\
\hline \multirow[t]{5}{*}{ Sig. (1-tailed) } & H_SAHAM & & .243 & .007 & .001 & .001 \\
\hline & ROA & .243 & & .000 & .061 & 161 \\
\hline & NPM & .007 & .000 & & .008 & .282 \\
\hline & DAR & .001 & .061 & .008 & & .280 \\
\hline & PER & .001 & 161 & .282 & .280 & \\
\hline \multirow[t]{5}{*}{$\mathrm{N}$} & H_SAHAM & 48 & 48 & 48 & 48 & 48 \\
\hline & ROA & 48 & 48 & 48 & 48 & 48 \\
\hline & NPM & 48 & 48 & 48 & 48 & 48 \\
\hline & DAR & 48 & 48 & 48 & 48 & 48 \\
\hline & PER & 48 & 48 & 48 & 48 & 48 \\
\hline
\end{tabular}

Sumber: SPSS 24, data diolah (2018)

Berdasarkan tabel tersebut menunjukkan nilai koefisien korelasi variabel ROA sebesar 0.103, variabel NPM sebesar 0.356, variabel DAR sebesar 0. 426 dan variabel PER sebesar 0.436. berdasarkan hal tersebut maka besaran konstribusis pengaruh masing-masing variabel independen terhadap variabel dependen dalam penelitian dapat dijelaskan pada tabel berikut ini:

Tabel 12

Kontribusi Independent variable terhadap dependent variabel

\begin{tabular}{|c|c|c|c|c|c|c|c|}
\hline $\begin{array}{c}\text { Variabel } \\
\text { Independen }\end{array}$ & \multicolumn{2}{|c|}{ Variabel Dependen } & $\begin{array}{c}\text { Koefisien } \\
\text { Korelasi (r) }\end{array}$ & \multicolumn{2}{|c|}{$\begin{array}{c}\text { Standardized } \\
\text { Coefficients Beta }\end{array}$} & & Kontribusi \\
\hline ROA (X1) & $==>$ & \multirow{4}{*}{$\begin{array}{l}\text { Harga } \\
\text { Saham }\end{array}$} & 0.103 & $\mathrm{X}$ & -0.108 & $=$ & -0.011 \\
\hline NPM (X2) & $==>$ & & 0.356 & $\mathrm{X}$ & 0.286 & $=$ & 0.102 \\
\hline DAR (X3) & $==>$ & & 0.426 & $\mathrm{X}$ & 0.319 & $=$ & 0.136 \\
\hline PER (X4) & $==>$ & & 0.436 & $\mathrm{X}$ & 0.368 & $=$ & 0.160 \\
\hline \multicolumn{6}{|c|}{ Kontribusi Total } & $=$ & 0.387 \\
\hline
\end{tabular}

a. Sumber: SPSS 24, data diolah (2018)

Authors : Andi Aspar Ramadhana dkk. (Agustus 2018). 47 - 65 


\section{JURNAL ORGANISASI DAN MANAJEMEN}

Issue 1 (Agustus, 2018)

\section{https://doi.org/10.31219/osf.io/79ext}

(1) Konstribusi Variabel ROA $\left(\mathrm{X}_{1}\right)=$ Standardized koefisien regresi ROA $\left(\mathrm{X}_{1}\right)$ sebesar -0.108dikalikan dengan koefisien korelasi hubungan ROA terhadap harga saham (Y) yaitu sebesar 0.103 sehingga besaran nilai konstibusi yaitu - 0.011 atau sebesar $-1,1 \%$

(2) Konstribusi Variabel NPM $\left(\mathrm{X}_{2}\right)=$ Standardized koefisien regresi NPM $\left(\mathrm{X}_{2}\right)$ sebesar 0.286 dikalikan dengan koefisien korelasi hubungan NPM (X2) terhadap harga saham (Y) yaitu sebesar 0.356 sehingga besaran nilai konstibusi yaitu 0.102 atau sebesar $10.2 \%$

(3) Konstribusi Variabel DAR $\left(\mathrm{X}_{3}\right)=$ Standardized koefisien regresi Variabel DAR (X3) sebesar 0.319 dikalikan dengan koefisien korelasi hubungan DAR (X3) terhadap harga saham (Y) yaitu sebesar 0.426 sehingga besaran nilai konstibusi yaitu 0.136 atau sebesar $13.6 \%$.

(4) Konstribusi Variabel PER (X4) = Standardized koefisien regresi Variabel PER (X4) sebesar 0.368 dikalikan dengan koefisien korelasi hubungan PER (X4) terhadap Kredit disalurkan (Y) yaitu sebesar 0.436 sehingga besaran nilai konstibusi yaitu 0.160 atau sebesar $16.0 \%$.

Berdasarkan hasil tersebut dapat disimpulkan bahwa variabel Price Earnig Ratio (PER, $\left.\mathrm{X}_{4}\right)$ memiliki pengaruh lebih dominan dibandingkan variabel lainya seperti Return On Asset (ROA, $\left.\mathrm{X}_{1}\right)$, Net Profit Margin (NPM, $\mathrm{X}_{2}$ ), Debt to Asset Ratio (DAR, $\mathrm{X}_{3}$ ), disebaban besaran konstribusi yang diberikan terhadap harga saham yaitu sebesar $16.0 \%$ yang lebih besar dibandingkan dengan konstribusi besaran pengaruh variabel independen lainnya.

\section{Interpretasi Hasil Penelitian}

\section{a) Pengaruh Return On Asset (ROA, $\mathrm{X}_{1}$ ) terhadap harga saham (Y)}

Rasio ini digunakan untuk mengukur kemampuan manajemen dalam memperoleh keuntungan (laba) secara keseluruhan. Semakin besar ROA, semakin besar pula tingkat keuntungan yang dicapai oleh perusahaan tersebut dan semakin baik pula posisi perusahaan tersebut dari segi penggunaan asset (Dendawijaya, 2003 dalam Rinati, 2012).Rasio ini penting diperhatikan untuk mengetahui sejauh mana investasi yang dilakukan investor disuatu perusahaan mampu memberikan return yang sesuai dengan tingkat yang diisyaratkan oleh investor.

Berdasarkan hasil pengujian parsial dalam penelitian ini menunjukkan bahwa Return On Asset (ROA) berpengaruh negatif dan tidak signifikan terhadap harga saham. Hasil penelitian ini mengindikasikan bahwa semakin rendah ROA yang dimiliki perusahaan maka tidak akan mampu memberikan pengaruh yang signifikan terhadap tingginya harga saham. hal ini dibuktikan pada hasil deskripsi data penelitian menunjukkan

Halaman 58

Authors : Andi Aspar Ramadhana dkk. (Agustus 2018). 47 - 65 


\section{JURNAL ORGANISASI DAN MANAJEMEN}

Issue 1 (Agustus, 2018)

https://doi.org/10.31219/osf.io/79ext

bahwa pada tahun 2017 emiten WIIM memiliki nilai ROA terendah pada triwulan ke dua dan berdampak pada harga saham yang dimilikinya dengan nilai harga saham 428 lebih rendah dibandingan arga saham pada triwulan pertama.

Hal ini disebabkan karena semakin rendah ROA maka daya tarik investor terhadap suatu perusahaan akan menurung karena investor menggap bahwa perusahaan yang memiliki tingkat ROA yang rendah maka artinya perusahaan tidak efektif dalam memanfaatkan aktiva untuk menghasilkan laba bersih setelah pajak. Hal ini tentunya akan membuat harga saham tidak dapat meningkat disebabkan kurangnya minat investor dalam mennamkan modalnya. Hasil penelitian ini sejalan dengan penelitian Aryani dan Zulkifli (2017). Bahwa secara parsial Return On Asset (ROA) tidak berpengaruh signifikan terhadap harga saham perusahaan real estate and property.

\section{b) Pengaruh Net Profit Margin (NPM, $\mathrm{X}_{2}$ ) terhadap harga saham (Y)}

Net Profit Margin (NPM) adalah rasio yang digunakan untuk menunjukkan kemampuan perusahaan dalam menghasilkan keuntungan bersih setelah dipotong pajak (Alexandri, 2008: 200).Semakin besar rasio ini, maka dianggap semakin baik kemampuan perusahaan untuk mendapatkan laba yang tinggi. Berdasarkan hasil pengujian parsial dalam penelitian ini menunjukkan bahwa Net Profit Margin (NPM) berpengaruh positif dan tidak signifikan terhadap harga saham. Hasil penelitian ini mengindikasikan bahwa Net Profit Margin (NPM) memiliki pengaruh yang kuat namun tidak mampu memberikan pengaruh atau konstribusi yang signifikan terhadap tingginya harga saham. Hal ini disebabkan karena perusahaan belum mampu mengahsilkan laba yang maksimal sehingga kinerja perusahaan masih tergolong rendah maka hal ini berdampak pada tidak signifikanya terhadap harga saham.

Berdasarkan analiis deskripsi data penelitian pada tahun 2014 menunjukkan bahwa pada emiten HMSP pada triwulan pertama memiliki NPM sebesar 15.05 lebih besar dibandingkan dengan triwulan berikutnya namun harga saham pada triwulan tersebut lebih rendah terhadap dibandingkan triwulan berikutnya. Hasil penelitian ini sejalan dengan penelitian Rinati (2012) bahwa secara parsial Net Profit Margin (NPM) berpengaruh positif tidak signifikan terhadap harga saham pada perusahaan yang tercantum dalam Indeks LQ45. 


\section{JURNAL ORGANISASI DAN MANAJEMEN}

Issue 1 (Agustus, 2018)

https://doi.org/10.31219/osf.io/79ext

c) Pengaruh Debt to Asset Ratio (DAR, $\mathrm{X}_{3}$ ) terhadap harga saham (Y)

Debt Ratio merupakan ukuran yang dipakai dalam menganalisis laporan keuangan untuk memperlihatkan besarnya jaminan yang tersedia untuk kreditor. Menurut Sartono (2010). Semakin tinggi Debt Ratio maka semakin besar resiko yang dihadapi, dan investor akan meminta tingkat keuntungan yang semakin tinggi. Rasio yang tinggi menunjukkan proporsi modal sendiri yang rendah untuk membiayai aktiva. hal ini akan direspon negatif oleh para investor di pasar modal.

Berdasarkan hasil pengujian parsial dalam penelitian ini menunjukkan bahwa Debt to Asset Ratio (DAR) berpengaruh positif signifikan terhadap harga saham. Hasil penelitian ini mengindikasikan bahwa walaupun rasio utang tergolong tinggi namun tetap mampu meberikan pengaruh yang signifikan terhadap harga saham. hal ini disebabkan karena investor menganggap bahwa tingginya tingkat utang yang dimiliki perusahaan mencerminkan bahwa perusahaan tersebut memiliki prospek yang baik di masa depan sehingga mendapat kepercayaan dari pihak luar untuk memperoleh pinjaman dan hal ini mengakibatkan daya tarik inestor terhadap saham perusahaan tersebut menjadi tinggi dan pada akhirnya berdampak pada harga saham.

Berdasarkan hasil deskripsi data penelitian menunjukkan bahwa emiten GGRM pada tahun 2017 di triwulan ke dua memiliki nilai DAR sebesar 0.40 lebih besar dari triwulan pertama tetapi harga saham pada triwulan tersebut sebesar 78.300 lebih tinggi dari triwulan sebelumnya. Selain itu hal ini disebabkan karena investor di dalam menginvestasikan modal mereka tidak terlalu mempertimbangkan rasio ini. sesuai pendapat Husnan dalam Kusuma (2009) bahwa terdapat empat faktor yang mendasari perubahan harga saham, faktor-faktor tersebutadalah: tingkat kegiatan industri, tingkat inflasi,perbedaan antara tingkat bunga jangka pendekdengan jangka panjang, perbedaan antara tingkatkeuntungan obligasi yang beresiko tinggi denganyang beresiko rendah. Hasil penelitian ini sejalan dengan penelitian Kusuma (2018) bahwa secara parsial Debt to Asset Ratio (DAR) berpengaruh positif signifikan terhadap harga saham pada perusahaan real estate and propertydi BEI.

\section{d) Pengaruh Price Earnig Ratio (PER, $\mathrm{X}_{4}$ ) terhadap harga saham (Y)}

Price earning ratio adalah rasio yang mengukur tentang bagaimana investor menilai prospek pertumbuhan perusahaan di masa yang akan datang, dan tercermin pada harga saham yang bersedia dibayar oleh investor untuk setiap rupiah laba yang diperoleh perusahaan (Sudana, 2009). Berdasarkan hasil pengujian parsial dalam penelitian ini 


\section{JURNAL ORGANISASI DAN MANAJEMEN}

Issue 1 (Agustus, 2018)

https://doi.org/10.31219/osf.io/79ext menunjukkan bahwa Price Earnig Ratio (PER)berpengaruh positif signifikan terhadap harga saham. Hasil penelitian ini mengindikasikan bahwa semakin tinggi Price Earnig Ratioyang dimiliki perusahaan maka semakin tinggi harga saham. Hasil lainya menjelaskan bahwa variabel Price Earnig Ratiomemiliki pengaruh yang kuat terhadap tingginya harga saham suatu perusahaan.

Hal ini disebabkan apabila perusahaan memiliki tingkat PER yang tinggi maka perusahaan tersebut memiliki peluang pertumbuhan yang tinggi dimasa yang akan datang dan tentunya akan menjadi sinyal positif bagi iinvestor didalam pengambilan keputusan pada saat ingin menginvestasikan modal mereka pada suatu perusahaan dan secara tidak langsung hal tersebut menyebabkan permintaan akan saham tersebut akan meningkat dan harga saham pun akan meningkat. Hal ini dibuktikan dari hasil deskripsi data penelitian pada tahun 2017 pada emiten HMSP di triwulan pertama memiliki nilai PER sebesar 141.43 lebih besar dari triwulan berikutnya dan nilai harga saham pada triwulan tersebut sebesar 3.900 lebih besar dari triwulan berikutnya. Hasil penelitian ini sejalan dengan penelitian Zuliarni (2013) bahwa secara parsial Price Earnig Ratio (PER) berpengaruh positif signifikan terhadap harga saham pada perusahaan mining and mining service di Bursa Efek Indonesia (BEI).

\section{Kesimpulan}

1. Hasil pengujian hipotesis mengenai pengaruh ROA terhadap harga saham dapat disimpulkan bahwa ROAberpengaruh negatif dan tidak signifikan terhadap harga saham. Hasil penelitian ini mengindikasikan bahwa semakin rendah ROA yang dimilki suatu perusahaan maka hal tersebut tidak akan mampu meningkatkan harga sama, selain itu hasil penelitian ini mengindikasikan bahwa ROA dalam penelitian ini tidak mampu memberikan konstribusi yang nyata atau signifikan terhadap harga saham perusahaan sektor rokok yang listing di BEI.

2. Pengaruh NPM terhadap harga saham, dapat disimpulkan bahwa NPM berpengaruh positif dan tidak signifikan terhadap harga saham. Hasil penelitian ini mengindikasikan bahwa perusahaan yang Net Profit Margin (NPM) yang tinggi belum mampu memberikan pengaruh atau konstribusi yang signifikan terhadap tingginya harga saham. Hasil ini menyimpulkan bahwa investor tidak menjadikan variabel ini sebagai faktor dalam pengambilan keputusan dalam berinvestasi tetapi melihat dari seberapa besar perusahaan mampu memberikan laba perlembar saham terhadap terhadap apa yang di investasikan.

3. Hasil pengujian hipotesis mengenai pengaruh DAR terhadap harga saham dapat disimpulkan bahwaberpengaruh positif dan signifikan terhadap harga saham. Hasil penelitian ini mengindikasikan bahwa DAR dalam penelitian ini tergolong tinggi namun hal tetap mampu memberikan 
Issue 1 (Agustus, 2018)

https://doi.org/10.31219/osf.io/79ext

pengaruh atau konstribusi yang signifikan terhadap tingginya harga saham. Keadaan ini disebabkan karena invenstor didalam pengambilan keputusan investasi tidak memperhatikan tingkat hutang yang dimiliki oleh perusahaan. Tetapi memperhatikan faktor lain seperti tingkat kegiatan industri, tingkat inflasi,perbedaan antara tingkat bunga jangka pendekdengan jangka panjang, perbedaan antara tingkatkeuntungan obligasi yang beresiko tinggi denganyang beresiko rendah. Selain itu juga investor menganggap hutang yang tinggi mencerminkan tingkat kepercayaan yang tinggi dari pihak luar sehingga perusahaan tersebut mampu mendapatkan pinjaman dari pihak luar.

4. Pengaruh PER terhadap harga saham, dapat disimpulkan bahwa berpengaruh positif dan signifikan terhadap harga saham. Hasil lainya menjelaskan bahwa variabel Price Earnig Ratiomemiliki pengaruh yang kuat dan tergolong tinggi terhadap tingginya harga saham suatu perusahaan. Hal ini disebabkan apabila perusahaan memiliki tingkat PER yang tinggi maka perusahaan tersebut memiliki peluang pertumbuhan yang tinggi dimasa yang akan datang dan tentunya akan menjadi sinyal positif bagi iinvestor didalam pengambilan keputusan pada saat ingin menginvestasikan modal mereka pada suatu perusahaan.

5. Berdasarkan hasil pengujian determinasi $\left(\mathrm{R}^{2}\right)$ menunjukkan bahwa variabel ROA, NPM, DAR, PER hanya mampu memberikan penjelasan pengaruh sebesar $38.7 \%$, sedangkan sisanya sebesar $61.3 \%$ dipengaruhi oleh faktor lain yang tidak dijelaskan dalam penelitian ini.

\section{SARAN}

1. Bagi Manajemen, disarankan agar pihak manajemen mampu memaksimalkan penggunaan assetnya sehingga nilai ROA akan tinggi dan tentunya hal tersebut akan memberikan konstribusi terhadap tingginya harga saham. selain itu disarankan pihak manajemen menjaga tingkat NPM yang dimiliki walaupun variabel tersebut tidak berpengaruh terhadap harga saham tetapi rendahnya NPM akan berdampak pada keberlangsungan perusahaan, hal ini dapat dilakukan dengan cara melakukan manajemen laba sebaik mungkin agar beban pajak yang dibeban kepada perusahaan tidak terlalu tinggi. Salain itu disarankan agar manajemen mampu menggunakan hutang yang dimiliki oleh perusahaan dengan maksimal seperti mengalokasikan hutang-hutang tersebut pada hal-hal yang dapat membantu perusahaan dalam meningkatkan pendapatan perusahaan seperti memperluas pasar dan lainya sebagainya, hal ini dilakukan agar tingkat kepercayaan dari pemberi hutang tetap terjaga dan tentunya ini akan menjadi signal positif bagi investor. Selanjutnya disarankan agar pihak manjemen tetap memaksimalkan nilai Price Earnig Ratio(PER) hal ini bisa dilakukan dengan cara meningkatkan

Halaman 62

Authors : Andi Aspar Ramadhana dkk. (Agustus 2018). 47 - 65 


\section{JURNAL ORGANISASI DAN MANAJEMEN}

Issue 1 (Agustus, 2018)

https://doi.org/10.31219/osf.io/79ext

EPS yang dimiliki perusahaan sehingga investor akan tertarik dengan saham tersebut dang secara langsung akan berdampak pada tingginya harga saham.

2. Bagi investor, dalam menginvestasikan modal yang mereka miliki hendaknya memperhatikan tingkat ROA yang dimiliki perusahaan karena ROA yang rendah akan berdampak pada rendahnya harga saham dan tentunya tingkat return saham pun akan mengalami penurunan. Nilai NPM yang dimiliki oleh perusahaan juga perlu menjadi bahan pertimbang karena walaupun variabel tersebut tidak berpengaruh signifikan terhadap harga saham tetapi variabel tersebut menjadi tolak ukur dari kemampuan perusahaan di dalam menghasilkan keuntungan bersih. Utang yang tinggi tidak selamanya menjadi kelemahan bagi perusahaan didalam menjalankan kegiatan operasinya tetapi utang yang tinggi menjadi cerminan bahwa peusahaan memiliki kinerja yang baik dimasa yang akan datang sehingga hal tersebut mejadi faktor yang menyebabkan tingginya tingkat kepercayaaan yang dimiliki perusahaan kepada pemberi pinjaman. Olehnya itu investor perlu mempertimbangkan hal ini di dalam pengambilan keputusan dalam berinvestasi. Selain itu disarankan agar investor didalam berinvestasi memperhatikan tingkat PER yang dimiliki oleh perusahaan karena PER yang tinggi mencerminkan bahwa hrga saham tersebut tergolong tinggi di pasar dan tentunya tingginya harga saham tersebut merupakan signal bahwa perusahaan tersebut memiliki prospek yang baik di masa akan datang.

3. Bagi peneliti lanjutan, peneliti selanjutnya sebaiknya menganalisis faktor yang mempengaruhi nilai perusahaan yang tidak saja dari sisi internal perusahaan namun juga dari sisi di luar perbankan seperti faktor makro ekonomi sehingga analisis yang dihasilkan dapat lebih menyeluruh dan seimbang, karena berdasarkan hasil uji deretminasi menunjukkan bahwa konstribusi yang diberikan oleh variabel independen dalam penelitian ini hanya sebesar $38.7 \%$, sedangkan sisanya sebesar $61.3 \%$ dipengaruhi oleh faktor lain yang tidak dijelaskan dalam penelitian ini, seperti inflasi, kurs dan lain sebagainya.

\section{Referensi}

Alexandri Moh. Benny, (2008), Manajemen Keuangan Bisnis, Cetakan Kesatu, Alfabeta, Bandung.

Anindita, N. P. (2017). Pengaruh CR, ROE, ROA, DAR, Dan DER Terhadap Harga Saham Pada Perusahaan Manufaktur Yang Listing Di Bursa Efek Indonesia Tahun 2011-2014 (Doctoral dissertation, Universitas Muhammadiyah Surakarta). 
Issue 1 (Agustus, 2018)

https://doi.org/10.31219/osf.io/79ext

Aryani, Y. A., \& Zulkifli, Z. (2017). Pengaruh Rasio Profitabilitas Terhadap Harga Saham Pada Perusahaan Industri Logam Dan Sejenisnya Yang Terdaftar Di Bursa Efek Indonesia Tahun 2007-2011. Jurnal ACSY, 4(1), 23-31.

Astuti, W. S., Sjahruddin, H., \& Purnomo, S. (2018). Pengaruh Reward dan Punishment Terhadap Kinerja Karyawan.

Bahar, A., \& Sjahruddin, H. (2017). Pengaruh Kualitas Produk Dan Kualitas Pelayanan Terhadap Kepuasan Konsumen Dan Minat Beli Ulang.

Brigham, Eugene F. dan Houston, Joel F. (2011). Dasar-dasar Manajemen. Keuangan Terjemahan. Edisi 10. Jakarta: Salemba Empat

Fahmi, Irham. (2012). Analisis Kinerja Keuangan , Bandung: Alfabeta

Fatmawati, H. R. S., \& Widyawati, D. (2017). Pengaruh kinerja keuangan terhadap harga saham pada perusahaan real estate and property. Jurnal Ilmu dan Riset Akuntansi, 6(8).

Fitri, S. A., \& Yahya, Y. (2016). Pengaruh Kinerja Keuangan Terhadap Harga Saham Perusahaan Food and Beverages di BEI. Jurnal Ilmu \& Riset Manajemen, 5(4).

Hutami, R. P. (2012). Pengaruh Dividend Per Share, Return On Equity Dan Net Profit Margin Terhadap Harga Saham Perusahaaan Industri Manufaktur Yang Tercatat Di Bursa Efek Indonesia Periode 2006-2010. Nominal, Barometer Riset Akuntansi dan Manajemen, 1(2).

Kasmir. (2014). Analisis Laporan Keuangan. Edisi Satu. Cetakan Ketujuh. Jakarta

Kusuma, D. I. (2018). Pengaruh Rasio Keuangan, Economic Value Added, Dan Market Value Added Terhadap Harga Saham Perusahaan Terindeks Pefindo 25. Kajian Bisnis STIE Widya Wiwaha, 26(1), 29-47.

Pamungkas, D. (2013). Kinerja Keuangan dan Harga Saham: Studi Pada Perusahaan Retail di Bursa Efek Indonesia. Sekolah Tinggi Ilmu Ekonomi Indonesia (STIESIA) Surabaya, Jurnal Ilmu dan Riset Manajemen, 1.

Rani, K. S., Nyoman, N., \& Diantini, A. (2015). Pengaruh Kinerja Keuangan Perusahaan Terhadap Harga Saham Dalam Indeks LQ45 di BEI. E-Jurnal Manajemen Unud, 4(6), 1526-1542.

Rinati, I. (2012). Pengaruh net profit margin (NPM), return on assets (ROA) dan return on equity (ROE) terhadap harga saham pada perusahaan yang tercantum dalam indeks LQ45.

Sardiyati. (2016). "Pengaruh Kinerja Keuangan Terhadap Harga Saham Perusahaan Sub Sektor Makanan dan Minuman di Bursa Efek Indonesia". eJournal Administrasi Bisnis, Volume 4, Nomor 3, 2016: 642- 656

Sartono, Agus. (2010) Manajemen Keuangan Teori dan Aplikasi, BPFE Yogyakarta 
Issue 1 (Agustus, 2018)

https://doi.org/10.31219/osf.io/79ext

Sjahruddin, H. (2014) Persepsi Mahasiswa Strata Satu Akuntansi Terhadap Pendidikan Profesi Akuntansi (PPAk)(Studi Pada Universitas Hasanuddin Makassar).

Sudana, I Made. (2009). Manajemen Keuangan: Teori dan Praktik. Surabaya: Airlangga .

Sunariyah. (2004). Pengantar Pengetahuan Pasar Modal. Yogyakarta: UPP AMP YKPN.

Sutrisno, (2000). Manajemen Keuangan. Ekonosia. Yogyakarta.

Tandelilin, Eduardus. (2010). Fortofolio dan Investasi. Yogyakarta: Konisius

Zuliarni, S. (2013). Pengaruh kinerja keuangan terhadap harga saham pada perusahaan mining and mining service di Bursa Efek Indonesia (BEI). Jurnal Aplikasi Bisnis, 3(1). 